\section{Comparative Dissolution Study of Different Brands of Amoxicillin Trihydrate Capsules Available in Bangladesh}

\author{
Naz Hasan Huda ${ }^{1^{*}}$, Yeakuty Marzan Jhanker ${ }^{2}$, A. F. M. Shahid-Ud-Daula ${ }^{3}$, \\ Most. Nazma Parvin ${ }^{1}$, Shammy Sarwar ${ }^{1}$ \\ Department of Pharmacy, Stamford University Bangladesh ${ }^{1}$ \\ 51 Siddeswari Road, Dhaka-1217 \\ Pharmacy Discipline, Khulna University, Khulna- $9100^{2}$ \\ Department of Pharmacy, Noakhali Science and Technology University ${ }^{3}$ \\ Sonapur, Noakhali-3802
}

${ }^{*}$ Corresponding Author

Naz Hasan Huda

Lecturer, Department of Pharmacy

Stamford University Bangladesh

Dhaka-1217, Bangladesh

Contact no.: +88 01199027212

Email: nazhasan@gmail.com

\begin{abstract}
Commercially available twenty national and four multinational brands of Amoxicillin Trihydrate capsules were studied in water for 60 minutes using USP reference dissolution apparatus. All, except two national brands (Code: NB-8 and NB-15); complied with the USP in vitro dissolution specification for drug release (not less than $80 \%$ of the labelled amount of amoxicillin trihydrate should be dissolved in 60 minutes). Drug releases from those two brands were $75 \%$ and $67 \%$ respectively within the specified time period.
\end{abstract}

Key words: In vitro Dissolution, Market preparations, Amoxicillin Trihydrate, Capsule, National Brand, Multinational Brand.

\title{
INTRODUCTION
}

Antibiotics, being the wonder drugs, are widely prescribed in the developing countries. In reality, 25 to $40 \%$ prescriptions contain one or more antibiotics (Public Sector Studies, 1990-1993). Amoxicillin is one of the extensively prescribed drugs within the list in the antibiotic therapeutic class (Hossain et al., 1982; Resi et al., 2003). Amoxicillin is a $\beta$-lactam antibiotic that interferes with the synthesis of the bacterial cell wall peptidoglycan. After attachment to binding sites on bacteria they inhibit the transpeptidation enzyme that cross-links the peptide chains attached to the backbone of the peptidoglycan. The final bactericidal event is the inactivation of an inhibitor of the autolytic enzymes in the cell wall; this leads to lysis of the bacterium (Rang et al., 2003).

Nowadays, antibiotic resistance by plasmid transfer has become a significant clinical problem, because an organism may become resistant to several antibiotics at the same time due to acquisition of a plasmid that encodes resistance to multiple agents (Lippincott's Illustrated Reviews: Pharmacology, 2008). Antibiotic resistance can be developed through its wide and inappropriate use without following any standard guidelines. This alarming situation has been addressed in several scientific journals (Glass et al., 1980; Farrar, 1985; Saha et al., 2003; Lina et al., 2007; Hasan et al., 2009)

Along with the inappropriate use of antibiotics, use of substandard antibiotic preparations may also contribute to the development of antibiotic resistance (Edelman et al., 1999). To assess the standard of a product, in vitro dissolution test is widely used because, for any solid dosage forms, gastrointestinal absorption first requires dissolution of the tablet or capsule that liberates the drug into solution (Goodman \& Gilman's - The Pharmacological basis of Therapeutics, 2006). The dissolution characteristic of a drug from the dosage form depends on many factors including its formulation and manufacturing process (Augsburger et al., 1983). This study deals with the comparative in vitro dissolution characteristics of some most commonly available national and multinational brands of amoxicillin trihydrate capsules in Bangladesh in order to find out any out of compliance market preparation. 


\section{MATERIALS AND METHODS}

Drug: Amoxicillin Trihydrate RS (Square Pharmaceuticals Limited, Bangladesh); Equipments: Tablet dissolution tester (Electrolab, India), UV spectrophotometer (Gamma, England), Electric balance (Mettler Toledo, Switzerland).

\section{Dosage forms}

Twenty national and four multinational brands of marketed (production date not more than three months ago from the time of purchase) amoxicillin trihydrate capsules were collected from various stores. The samples were properly checked for their manufacturing licence number, batch number, manufacturing and expiry dates before purchasing. The samples were randomly coded as NB-n for national brands, where $n=1,2,3,4, \ldots \ldots \ldots 19,20$ and MB- $n$ for multinational brands, where $n=1$, 2, 3 and 4. The labelled active ingredient was Amoxicillin Trihydrate $500 \mathrm{mg}$ and packaged in strip or in blister packing. The strip or blister packs were stored at $25 \pm 2{ }^{\circ} \mathrm{C}$ for four weeks before the dissolution study in order to evaluate any change in organoleptic properties.

\section{In vitro dissolution Study}

These studies were conducted at $37 \pm 0.5^{\circ} \mathrm{C}$ on an USP specification dissolution rate test type II apparatus (Paddle apparatus) with six sections assembly according to the USP 30 procedure (USP 30 and NF 25, 2007). For in vitro dissolution studies, water was used as dissolution media.

The water-bath temperature was fixed \& confirmed to be $37 \pm 0.5^{\circ} \mathrm{C}$ before starting the experiment. The medium was preheated to $37^{\circ} \mathrm{C}$ and then a quantity of $900 \mathrm{ml}$ was added to each vessel. The apparatus was then assembled and paddle rotation was started and adjusted at $75 \mathrm{rpm}$ and the system was allowed to equilibrate for 15 minutes. After that the paddle rotation was stopped and six capsules from same code were placed in the vessels (one capsule per vessel) and allowed to sink to the bottom. The apparatus was immediately operated at $75 \mathrm{rpm}$. Each vessel, vessel position and corresponding sample result were assigned the same code. The duration of the experiment was 60 minutes for each set of sample. At the end of the experiment, $10 \mathrm{ml}$ of sample solution was withdrawn, filtered, diluted and analyzed at $272 \mathrm{~nm}$ for amoxicillin trihydrate by UV spectrophotometer. The amount of drug present in the samples was calculated from calibration curve constructed from the standard solution of USP reference standard test drug (Fig. 1).

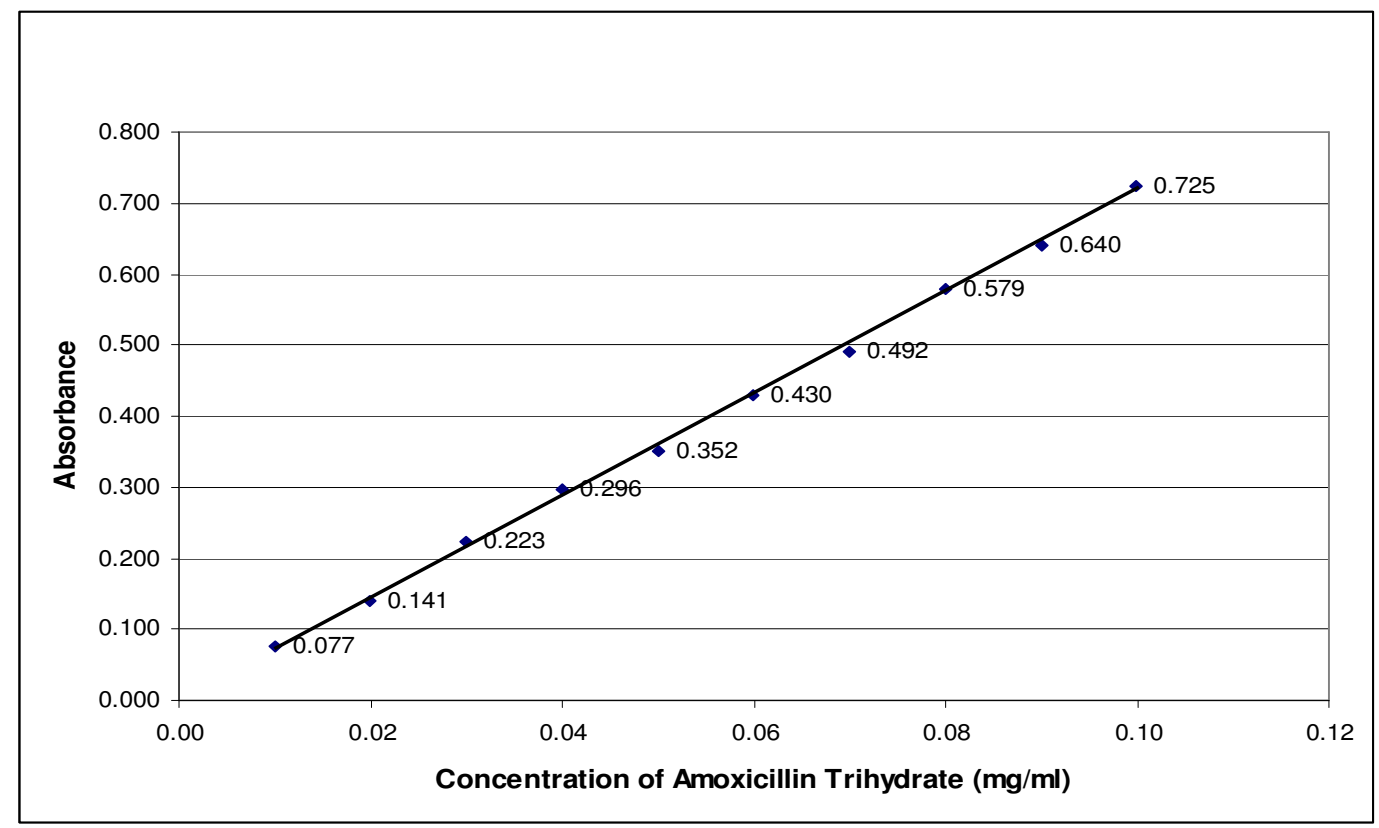

Figure 1: Calibration curve of Amoxicillin Trihydrate.

\section{RESULTS AND DISCUSSION}

According to USP, not less than $80 \%$ of the labeled amount of amoxicillin trihydrate should be dissolved in 60 minutes. The following table shows the dissolution data for each sub sample of each brand. Except two national brands (Code: NB-8 and NB-15), all the brands met the official 
standard. These two brands were tested again according to BP (British Pharmacopoeia, 2003); however the results remained identical to the first one.

Table 1: Dissolution percentages for Amoxicillin Trihydrate samples

\begin{tabular}{cccccccccc}
\hline & \multicolumn{7}{c}{ Dissolution of Sub-samples (\%) } & & \\
\cline { 2 - 5 } Code & $\mathbf{1}$ & $\mathbf{2}$ & $\mathbf{3}$ & $\mathbf{4}$ & $\mathbf{5}$ & $\mathbf{6}$ & \%RSD & USP Standard \\
\hline NB-1 & 89 & 89 & 90 & 89 & 90 & 90 & 0.61 & Complies \\
NB-2 & 87 & 88 & 89 & 89 & 89 & 87 & 1.12 & Complies \\
NB-3 & 90 & 90 & 91 & 91 & 91 & 90 & 0.61 & Complies \\
NB-4 & 83 & 87 & 88 & 88 & 83 & 85 & 2.73 & Complies \\
NB-5 & 88 & 87 & 88 & 88 & 88 & 88 & 0.46 & Complies \\
NB-6 & 84 & 86 & 86 & 86 & 85 & 85 & 0.96 & Complies \\
NB-7 & 89 & 90 & 90 & 90 & 90 & 90 & 0.45 & Complies \\
NB-8 & 70 & 71 & 75 & 70 & 70 & 71 & 2.73 & Does not comply \\
NB-9 & 85 & 84 & 85 & 85 & 85 & 84 & 0.61 & Complies \\
NB-10 & 83 & 83 & 84 & 84 & 84 & 83 & 0.66 & Complies \\
NB-11 & 90 & 90 & 93 & 91 & 93 & 92 & 1.51 & Complies \\
NB-12 & 90 & 91 & 90 & 92 & 92 & 90 & 1.08 & Complies \\
NB-13 & 86 & 86 & 86 & 85 & 86 & 86 & 0.48 & Complies \\
NB-14 & 85 & 85 & 87 & 87 & 87 & 85 & 1.27 & Complies \\
NB-15 & 63 & 64 & 66 & 67 & 66 & 67 & 2.51 & Does not comply \\
NB-16 & 89 & 89 & 90 & 90 & 89 & 90 & 0.61 & Complies \\
NB-17 & 90 & 92 & 95 & 93 & 95 & 93 & 2.04 & Complies \\
NB-18 & 91 & 92 & 93 & 93 & 91 & 92 & 0.97 & Complies \\
NB-19 & 86 & 87 & 89 & 88 & 88 & 87 & 1.20 & Complies \\
NB-20 & 87 & 87 & 87 & 87 & 88 & 88 & 0.59 & Complies \\
MB-1 & 93 & 94 & 93 & 95 & 94 & 94 & 0.80 & Complies \\
MB-2 & 90 & 90 & 91 & 90 & 91 & 91 & 0.61 & Complies \\
MB-3 & 95 & 95 & 95 & 92 & 95 & 92 & 1.65 & Complies \\
MB-4 & 86 & 88 & 86 & 88 & 87 & 86 & 1.13 & Complies \\
\hline & & & & & & & & \\
\hline
\end{tabular}

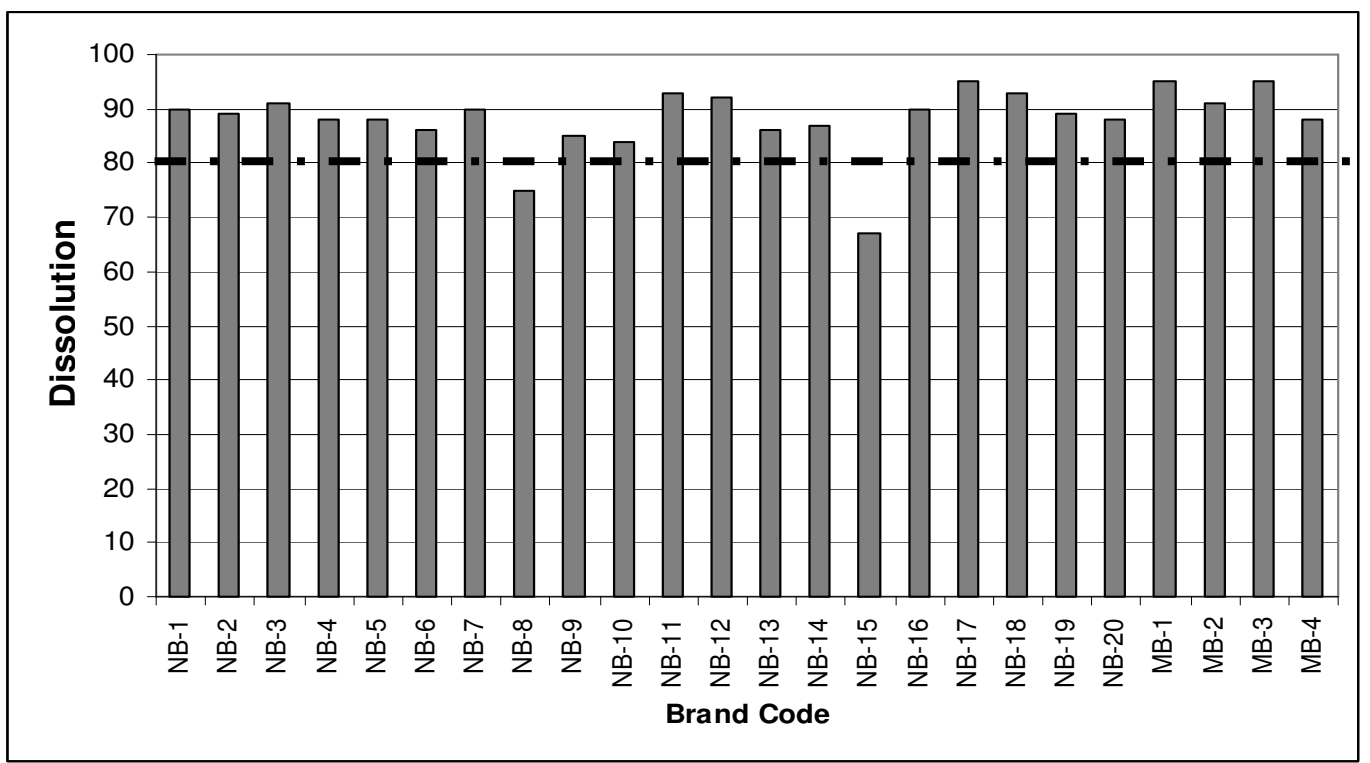

Figure 2: Comparison of dissolution percentages among different brands of Amoxicillin Trihydrate.

For ease of perception, the highest values from the six sub-samples of all the brands are taken to compare the values across different brands. The following figure (Fig. 2) clearly shows the failure of two brands to comply with the USP standard of $80 \%$ drug release within 60 minutes (this has been marked with the dot-dash line). The potency of each brand under investigation was also determined by spectrophotometric method and it was found that all the brands met the official standard, although few of them were at lower region within the specified standard. Along with the 
formulation defects, this may contribute significantly towards the substandard dissolution characteristic of the above discussed samples.

\section{CONCLUSION}

From this study it has been revealed that most of the commercially available brands of amoxicillin trihydrate capsule in Bangladesh fulfilled the official specification of dissolution test, although few of them failed which might be explained by poor formulation and/or lower content of the active ingredient. To fight the challenge of antibiotic resistance effectively, first the pharmaceutical companies have to supply efficacious drug to the market.

\section{REFERENCES}

Augsburger LL, Shangraw RF, Giannini RP, Shah VP, Prasad VK and Brown D (1983) Thiazides VIII: Dissolution Survey of marketed Hydrochlorothiazide tablets. J. Pharm. Sci., 72(8): 876881.

British Pharmacopoeia (2003) British Pharmacopoeia Commission Office, Market Towers, London. CD ROM.

Edelman R, Okeke IN and Lamikanra A (1999) Socioeconomic and behavioral factors leading to acquired bacterial resistance to antibiotics in developing countries. Emerging Infectious Diseases, 5(1): 18-27.

Farrar WE (1985) Antibiotic resistance in developing countries. The Journal of Infectious Diseases, 152(6): 1103-1106.

Glass RI, Huq I, Alim ARM and Yunus M (1980) Emergence of multiply antibiotic-resistant vibrio cholerae in Bangladesh. The Journal of Infectious Diseases, 142(6): 939-942.

Goodman \& Gilman's - The Pharmacological basis of Therapeutics (2006) 11th Edition, McGrawHill Medical Publishing Division, Digital Edition, Chapter 1.

Hasan SMR, Hossain MM, Akter R, Karim SMH, Haque S, Kamaluddin M and Ghani A (2009) Pattern of antibiotics use at the primary health care level of Bangladesh: Survey report-1. S. J. Pharm. Sci. 2(1): 1-7.

Hossain MM, Glass RI and Khan MR (1982) Antibiotic use in a rural community in Bangladesh. International Journal of Epidemiology, 11(4): 402-405.

Lina TT, Rahman SR, Gomes DJ (2007) Multiple-antibiotic resistance mediated by plasmids and integrons in Uropathogenic escherichia coli and Klebsiella pneumoniae. Bangladesh Journal of Microbiology, 24(1): 19-23.

Lippincott's Illustrated Reviews: Pharmacology (2008) 4th Edition, Lippincott Williams \& Wilkins. pp.362-363.

Public Sector Drugs Use Studies (1990-1993) International Network for Rational Use of Drugs, Virginia, USA.

Rang HP, Dale MM, Ritter JM and Moore PK (2003) Rang \& Dale's Pharmacology, 5th Edition, Churchill, Livingstone, Edinburgh. pp639-643.

Resi $\mathrm{D}$, Milandri $\mathrm{M}$, Moro $\mathrm{ML}$ and the Emilia Romagna study group on the use of antibiotics in children (2003) Antibiotic prescriptions in children, Journal of Antimicrobial Chemotherapy, 52: $282-286$.

Saha SK, Baqui AH, Darmstadt GL, Ruhulamin M, Hanif M, Arifeen SE, Santosham M, Oishi K, Nagatake T and Black RE (2003) Composition of carriage and invasive pneumococci among Bangladeshi children: implications for treatment policy and vaccine formulation. Journal of Clinical Microbiology, 41(12): 5582-5587.

United States Pharmacopeia 30 and National Formulary 25 (2007) The United States Pharmacopeial Convention, CD ROM. 